\title{
Bee diversity in secondary forests and coffee plantations in a transition between foothills and highlands in the Guatemalan Pacific Coast
}

\author{
Gabriela Armas-Quiñonez \\ , Ricardo Ayala-Barajas ${ }^{4}$, Carlos Avendaño-Mendoza ${ }^{5}$, Roberto Lindig-Cisneros ${ }^{2}$, Ek \\ del-Val ${ }^{\text {Corresp. } 2}$ \\ Posgrado en Ciencias Biológicas, Universidad Nacional Autónoma de México, Ciudad de México, Mexico \\ 2 Instituto de Investigaciones en Ecosistemas y Sustentabilidad, Universidad Nacional Autónoma de México, Morelia, Michoacán, Mexico \\ ${ }^{3}$ Centro de Estudios Conservacionistas, Universidad de San Carlos de Guatemala, Guatemala, Guatemala \\ 4 Estación de Biología-Chamela, Instituto de Biología, Universidad Nacional Autónoma de México, Chamela, Jalisco, Mexico \\ 5 Escuela de Biología, Universidad de San Carlos de Guatemala, Guatemala, Guatemala \\ Corresponding Author: Ek del-Val \\ Email address: ekdelval@iies.unam.mx
}

Background. Although conservation of pristine habitats is recognized in many countries as crucial for maintaining pollinator diversity, the contribution of secondary forest conservation is poorly recognized in the Latin American context, such as in Guatemala. San Lucas Tolimán (SLT) is a high-quality coffee production region from the Atitlan Province, which has the second highest deciduous forest cover in Guatemala and pristine forest is prioritized for conservation. In contrast, secondary forest protection is undetermined, since these forests are normally removed or strongly affected by coffee farming practices. This situation may affect the diversity of native pollinators, mainly bees, which usually rely on the secondary forest for food resources. Methods. We conducted a study to investigate the importance of secondary forests around the SLT coffee plantations (Coffea arabica L.) for pollinators. We compared bee diversity (richness, abundance and composition) in secondary forests of different age and coffee plantations with diverse farming techniques. Being the first study of pollinators in Guatemalan coffee plantations, we also recorded data for an entire year (2013-2014) in order to describe bee seasonality. Results. We found significant differences in bee diversity between the coffee plantations and secondary forests, particularly early secondary forests showed higher bee abundances but diversity indices were similar between different vegetation type plots. In the early dry season, secondary forests showed the greatest native bee diversity. During the late dry season, when the coffee was flowering, honey bees were dominant in the same plots. This study provides important management insights to support the conservation of pollinators, since our results offer guidelines to improve coffee production by increasing native pollinator diversity. 
1 Bee diversity in secondary forests and coffee plantations in a transition between foothills

2 and highlands in the Guatemalan Pacific Coast

3

4 Ana Gabriela Armas-Quiñonez ${ }^{1,2}$, Ricardo AyalaBarajas 3 ; Carlos Avendaño-Mendoza ${ }^{4}$; Roberto

$5 \quad$ Lindig-Cisneros ${ }^{1} ;$ Ek del- Val $^{1}$.

7 Instituto de Investigaciones en Ecosistemas y Sustentabilidad, Universidad Nacional Autónoma

8 de México (UNAM), Morelia, Michoacán, México

9 2Centro de Estudios Conservacionistas, Universidad de San Carlos de Guatemala, Guatemala

10 [3Estación de Biología Chamela, Instituto de Biología, Universidad Nacional Autónoma de

11 México (UNAM), Chamela, Jalisco, 48980, México

$12{ }^{4}$ Escuela de Biología, Universidad de San Carlos de Guatemala, Guatemala

13 Corresponding author:

14 Ek del-Val

15 Antigua Carretera a Pátzcuaro No. 8701, Col. Ex-Hacienda de San José de La Huerta, C.P.

16 58190, Morelia, Michoacán, México

17 Email address: ekdelval@iies.unam.mx

19 Abstract

Background. Although conservation of pristine habitats is recognized in many countries as crucial for maintaining pollinator diversity, the contribution of secondary forest conservation is poorly recognized in the Latin American context, such as in Guatemala. San Lucas Tolimán (SLT) is a high-quality coffee production region from the Atitlan Province, which has the second highest deciduous forest cover in Guatemala and pristine forest is prioritized for conservation. In 
25 contrast, secondary forest protection is undetermined, since these forests are normally removed

26 or strongly affected by coffee farming practices. This situation may affect the diversity of native

27 pollinators, mainly bees, which usually rely on the secondary forest for food resources.

28 Methods. We conducted a study to investigate the importance of secondary forests around the

29 SLT coffee plantations (Coffea arabica L.) for pollinators. We compared bee diversity (richness,

30 abundance and composition) in secondary forests of different age and coffee plantations with

31 diverse farming techniques. Being the first study of pollinators in Guatemalan coffee plantations,

32 we also recorded data for an entire year (2013-2014) in order to describe bee seasonality.

33 Results. We found significant differences in bee diversity between the coffee plantations and

34 secondary forests, particularly early secondary forests showed higher bee abundances but

35 diversity indices were similar between different vegetation type plots. In the early dry season,

36 secondary forests showed the greatest native bee diversity. During the late dry season, when the

37 coffee was flowering, honey bees were dominant in the same plots. This study provides

38 important management insights to support the conservation of pollinators, since our results offer

39 guidelines to improve coffee production by increasing native pollinator diversity.

40

41 Key words: pollination, bee diversity, Apoidea, secondary forest, insect conservation, coffee 42 plantations.

\section{Introduction}

45 Rates of land-use change in primary forests are increasing worldwide, threatening biodiversity

46 (Montero-Castaño and Vilà, 2012). As a result, secondary forests become alternative habitats and

47 resource providers that promote a faunal diversity more characteristic of primary forest (Peters et 
48 al., 2013; Taki et al. 2013). In tropical forests, one of the most threatened groups of fauna

49 interacting in both primary and secondary forests are the pollinators (Winfree et al., 2011;

50 Cariveau and Winfree 2015), a fact that highlights the importance of also conserving secondary

51 forests (Taki et al. 2013, Winfree et al., 2011).

52 The conservation strategy in Guatemala for the past twenty-five years has been to

53 preserve primary forest in situ (National Congress Decrees, 1989) by creating protected areas

54 without management strategies to preserve the primary forest surroundings. As a result of this

55 policy, the people in Guatemala are unaware of the role or ascribe little importance to secondary

56 forest in terms of conserving biodiversity. In San Lucas Tolimán in Sololá, Guatemala,

57 secondary forest is also underestimated; here, the traditional and conventional coffee farmers

58 focus their conservation efforts on the pristine forest, mainly to ensure ecosystem services such

59 as pollination and water provision. This is a good strategy for the conservation of native

60 pollinators who nest in this forest (Jha and Dick, 2010; Klein et al., 2003; Klein et al., 2008; Rao

61 and Stephen, 2010; Ricketts, 2004; Ricketts et al. 2008). However, many native pollinators also

62 require secondary forest to obtain food resources throughout the year (Jha and Dick, 2010;

63 Badano and Vergara, 2011; Klein et al., 2008; Kremen et al., 2004) and these are also important

64 for maintaining biodiversity in general (Jules and Shahani, 2003; Kohler, 2007; Kremen et al.,

65 2004; Kremen et al., 2007; Mandelik and Roll, 2009).

66

As some authors have suggested (Klein et al., 2007; Kremen et al., 2002, Ollerton et al.,

67 2011; Winfree et al, 2007), among the vertebrate and invertebrate pollinators, bees are the most

68 important pollination agents. Bees are responsible for pollinating nearly two thirds of crops

69 worldwide (Brauman and Daily, 2008, Kremen et al., 2002); however, climate change and

70 habitat fragmentation have endangered bee diversity and reduced bee populations, leading to a 
71 food crisis worldwide. Conservation of pollinators has therefore emerged as an issue of great 72 importance (Abrol et al., 2012; Ollerton et al. 2011).

Around the world, two species of coffee dominate the world market, Coffea canephora $\mathrm{L}$.

74 y Coffea arabica L., the second being the one that dominates more than $60 \%$ of it (Ngo, et. al.

75 2011). The global coffee market has suffered price fluctuations, however this has not meant that

76 the cultivation has decreased (Ngo, et. al. 2011). In recent years, Guatemala has become the

77 seventh largest coffee producer in the world and it is the most important crop in the country in

78 terms of the employment and the foreign exchange that it produces (Anacafé, 2014). Sololá is a

79 high-quality coffee region and crop fields are gaining territory at the expense of the forest due to

80 the high demand for coffee produced in the region (Anacafé, 2014; Fischer and Victor, 2014).

81 At present in San Lucas Tolimán, the secondary vegetation commonly known as "monte"

82 is normally cut down or treated with herbicides to prevent the secondary growth. Conventional

83 farmers argue that by keeping the surroundings of the coffee clean they reduce the incidence of

84 coffee pests, although there is no scientific evidence to support this belief. They also believe that

85 by maintaining some primary forests they can guarantee pollinator diversity. On the other hand,

86 the indigenous people who practice traditional farming are aware of the importance of secondary

87 vegetation (Armas-Quiñonez Pers. Obs.). Through their traditional knowledge, they know that

88 these represent a habitat for numerous important species. However, they also cut down all the

89 secondary growth in common areas, arguing that it is for the safety of the children and for

90 aesthetic purposes. In both cases, the secondary vegetation is removed. As a consequence, the

91 area with secondary vegetation in the region could be insufficient to maintain the community of

92 native bee pollinators, especially when the coffee is not in flower. In other words, the traditional

93 and conventional coffee farmers are not aware of the critical importance of secondary forest to 
94 the preservation of the pollinators, a situation that must be addressed in Guatemala since it could

95 lead to loss of biodiversity and subsequently to deficient coffee production (Philpott et al., 2008;

96 Scheper et al., 2013; Steffan-Dewenter and Westphal, 2008).

97 In order to ensure production and obtain other income sources, coffee farmers of the

98 Guatemalan highlands have introduced Apis mellifera hives into their farms. It has been shown

99 that coffee is mainly pollinated by the honey bee but also frequently visited by stingless bees

100 (Ngo, et. al. 2011). However, the raising honey bees within coffee farms is practice may present

101 some risk since it could have unknown impacts on native bee populations (Badano and Vergara,

102 2011; Garibaldi et al., 2011; Shavit et al., 2009; vanEngelsdorp and Meixner, 2010; Winfree et

103 al., 2007), particularly in Guatemala where such interactions are poorly studied.

104 Coffee farming in Guatemala is very heterogeneous in terms of farming techniques. Big

105 farms have changed from traditional management to conventional and highly intensive farming

106 techniques that usually include higher inputs of agrochemicals, mainly pesticides, or on rare

107 occasions have changed to integrated pest management (IPM). At the same time, traditional

108 farmers use multi-farming techniques, where small coffee plantations are cultivated using

109 intercropping with several banana hybrids (Musa x paradisiaca), papaya (Carica papaya),

110 macuy (Solanum americanum), besides other crops. Traditional farmers usually cannot afford

111 agrochemicals (pesticides, herbicides and fertilizers) to spray on their fields, and this

112 management could therefore be contributing more than conventional coffee cultivation to the

113 maintenance of bee diversity (Schmitt, 2006; Schuepp et al., 2012). However, in Guatemala,

114 there have been no studies published that address this issue.

115 This study was therefore conducted in order to investigate the importance of secondary

116 forests in maintaining pollinator diversity around the San Lucas Tolimán coffee fields. To 
117 accomplish this goal, the study was designed to compare bee diversity in plots featuring different

118 stages of secondary forest and in coffee fields managed under a range of farming practices.

119

120 Materials \& Methods

\section{Study sites}

122 This study was conducted from March 2013 through February 2014 in San Lucas Tolimán

123 foothills region (Appendix 1a). San Lucas Tolimán is located at the limit between the central

124 highlands and costal lowlands in southeastern Guatemala, where many Kaqchikel indigenous

125 people live. San Lucas Tolimán is bordered by two volcanoes, Atitlán and Tolimán that range

126 from 800 to 3500 masl and produce a variety of microhabitats. According to the Villar

127 classification, the primary vegetation of studied farms are within a subtropical humid forest,

128 where broadleaf evergreen forest divides the mountain forest from the tropical humid savanna on

129 the Pacific coast (Villar, 1998). These biotic and topographic differences give the area a dynamic

130 ecotone with high precipitation (Villar, 1998; 2003). According to the Guatemalan National

131 Council of Protected Areas (Consejo Nacional de Áreas Protegidas, 2013), the department of

132 Sololá, where San Lucas Tolimán is located, has 35\% forest cover, making it the most forest-

133 covered department in Guatemala. This fact is associated with the high degree of community

134 conservation but is also due to the presence of private farms that normally have their own forest 135 reserves.

136

137 Sampling design

138 Sampling was conducted at three coffee farms with different management types (Table 1). The

139 farms harvest Coffea arabica, cultivar "caturra". The three farms have secondary forests nearby, 
140 farm 1 and 3 are separated by $0.8 \mathrm{~km}$, and $4 \mathrm{~km}$ from farm 2 (Appendix $1 \mathrm{~b}$ ). The names of these

141 private farms must be withheld at the request of the owners.

142 In each of the studied farms, three plots of $60 \mathrm{~m}^{2}$ were established. Each plot was

143 categorized as early secondary growth, late secondary growth or coffee plantation, the plots

144 within the farm were separated by at least $0.5 \mathrm{~km}$ depending on the farm. Early secondary

145 growth was characterized by early secondary forest with up to one year of development, mainly

146 herbaceous vegetation with few bushes and an abundant incidence of light. Late secondary

147 growth was characterized by late secondary forest with two to three years of succession, with

148 mainly shrub vegetation and luminosity slightly restricted below the high bushes. Coffee plots

149 were selected in patches of shaded coffee in the selected farms. Plot characteristics are presented 150 in Table 1.

151

\section{Bee sampling}

153 Bees were sampled every month from March 2013 to February 2014 in each vegetation type plot,

154 covering the two Guatemalan climatic seasons established as dry or summer from November to 155 April and rainy or winter from May to October (CONAP, 2008). During three days each month, 156 five people searched for bees on flowering plants in all of the selected plots. For each flowering 157 plant species in each plot, bee sampling was conducted for 40 mins at different times between 158 8:00 to 12:00 p.m. The sampling schedule was done considering results of previous temperature 159 and humidity monitoring where optimal conditions for bee activity in the area were established.

160 Bee sampling was based on the direct search method on flowers, using net sweeping (Brosi et al., 161 2008; McGavin, 1997; McMullen, 1965). Bees captured from flowers were killed by freezing in 162 individual containers. Native bee (no honey bee) specimens were mounted on insect pins labeled 
163 with field data and assigning a unique code for deposition in the "Colección de abejas nativas del

164 Centro de Estudios Conservacionistas de la Universidad de San Carlos de Guatemala". In

165 contrast, honey bee specimens were sampled and recorded but not mounted. Taxonomical keys

166 were used for bee identification to genus or species (wherever possible) (Ayala 1990, 1999;

167 Michener 2007; Michener et al. 1994; McGinley 1986; Roberts 1972; Roubik and Hanson 2004;

168 Smith-Pardo 2005; Snelling 1974) and with the help of the bee expert Ricardo Ayala, and

169 collaboration of Mabel Vásquez, Carmen Yurrita y María José Dardón. Collection

170166 permits for conducting bee and plant sampling are 000960, 002011, 002009, and the Field

171167 Research License were 007/2015 and 043/2012.

172

173 Data analysis

174 Seasonal bee and plant abundance across vegetation types. In order to analyze changes in

175 plant and bee abundance per season and vegetation type, we used nested ANOVAs considering 176 several response variables: plant richness, total bee abundance, stingless bee abundance, social

177 bee abundance, honey bee abundance and native bee abundance, as well as abundance per family

178 and we included vegetation type, season and the interaction between vegetation type and season

179 as explanatory variables, we also added an error term to account for spatial and temporal

180 pseudoreplication considering farm/season/vegetation type. All response variables were log

181 transformed to comply with ANOVA requirements. Also, Pearson correlations were performed

182 in order to determine whether bee richness was correlated with plant richness, and also if honey

183 bee incidence, was correlated with other native bee groups over the study seasons. We grouped

184 the bees into honey bees, native bees and stingless bees with the aim of differentiating the

185 contribution of introduced honey bees, from stingless bees, which are the second largest group of 
186 bees that visit coffee (Ngo, et. Al. 2011) and also of the rest of native bees that are generally

187 seasonal.

188

189 Bee diversity in coffee fields and the surrounding secondary forest. Global bee diversity

190 (considering all the sampling period) was evaluated by comparing the secondary forests and

191 coffee plantations, with the three different farming management type (Table 1). For richness, we

192 used the Chaol index and Abundance-based Coverage Estimator (ACE), in order to take both

193 rare and abundant bee species into account. The incidence of both rare and common bee species

194 was estimated with the Chao2 and Incidence Covered Estimator (ICE) indices. Diversity was

195 calculated by Shannon-Wiener $(\mathrm{H})$. These indices were calculated using the EstimateS Program

196 (Colwell, 2013). All the diversity indices were analyzed using ANOVAs, taking into account the

197 vegetation type and farming management type as explanatory variables.

$198 \quad$ Finally, a cluster analysis with Euclidean distances with 100 bootstrap samples was

199 performed, using the bee diversity data to look for similarities between the vegetation and

200 farming techniques (farms) and to infer the importance of the coffee management for the bees.

201 All the analysis were performed using the R program (R Core Team, 2014) using the packages

202 stats, vegan (Oksanen, et. al. 2019) and Pvclust (Suzuki, et.al. 2019).

203

204 Results

205 Seasonal richness and abundance. Over one year of study, 3,004 bee specimens, belonging to

206102 species (Appendix 2) and 100 species of flowering plants with visiting bees (Appendix 3)

207 were recorded. Bee and plant richness inside plots were significantly correlated $\left(\mathrm{t}_{36}=7.82\right.$,

$208 \mathrm{p}=2.8 \mathrm{e}^{-09}$, cor $=0.79$ ) showing a close relationship between them (Fig. 1a). 
210 flowering in the early dry season from November 2013 to February 2014, closely reflecting the

211 two climatic seasons in Guatemala. A few months after the lowest records of bee abundance

212 (March to October 2013), the rainy season promoted vegetative growth in the secondary forest,

213 and it was correlated with the highest values of flowering plant richness with a $21 \%$ increase

214 (Fig. 2 and Appendix 3).

215 Plant richness was similar between seasons $\left(\mathrm{F}_{1,1}=2.53, \mathrm{P}=0.37\right)$, as well as total bee

216 abundance and richness $\left(\mathrm{F}_{1,1}=40.6, \mathrm{P}=0.09\right.$ and $\mathrm{F}_{(1,1)}=66.1, \mathrm{P}=0.07$, respectively $)$. However, bee 217 groups responded in different ways, native bees and social bees showed higher abundances

218 during the dry season $\left(\mathrm{F}_{(1,1)}=195.4, \mathrm{P}=0.05, \mathrm{~F}_{(1,1)}=118.5, \mathrm{P}=0.05\right.$, respectively $)$ while honey bee 219 and stingless bee abundance showed a similar seasonal trend but was no statistically significant $220\left(\mathrm{~F}_{1,1}=19.1, \mathrm{P}=0.1 ; \mathrm{F}_{1,1}=72.9, \mathrm{P}=0.07\right.$, respectivelysee Table 2$)$. There was an interesting finding 221 in February 2014 (Fig. 2) when bee richness increased by 57\% (from 28 to 53 species),

222 presenting the highest value in the study, but out of phase with respect to the peak of local

223 flowering plants (December 2013), coinciding with the beginning of drought, with the biggest

224 drop of flowering (14\%). In the following month when the coffee plants were flowering (March 225 2014), the greatest number of bees was recorded (437 records), but the native bee species began 226 to decrease $(10 \%)$.

227 Interestingly, honey bees and stingless bees were significantly and positively correlated $228\left(\mathrm{r}=0.62, \mathrm{t}_{36}=4.78, \mathrm{p}=2.95 \mathrm{e}^{-05}\right.$, Fig. $\left.1 \mathrm{~b}\right)$, as were the honey bees and native bees $\left(\mathrm{r}=0.61, \mathrm{t}_{36}=4.61\right.$, $229 \mathrm{p}=4.84 \mathrm{e}^{-05}$, Fig. 1c). Highlighting that for the three groups of bees, the availability of floral 230 resources is important for their activity. 
232 Bees in coffee plantations and the surrounding secondary forest. The farms presented

233 different bee richness and abundance. As shown in Figure 3, farm 1 had the highest number of

234 bees followed by farm 2 and farm 3 . Farms 1 and 2 presented the highest bee abundance in plots 235 with secondary forest, while in farm 3 the coffee plantations presented the highest abundance.

Bee richness mainly comprises five families (Fig. 3). Most of the bees are Apidae

237 (84.8\%), followed by Halictidae (8.9\%), Andrenidae (2.6\%), Megachilidae (2.3\%) and

238 Colletidae (1.5\%). Species from the five bee families were registered in the three farms. On farm $2393,91 \%$ of captures belonged to Apidae, while farms 1 and 2 had a higher representation of

240 Colletidae and Andrenidae. Vegetation type (early secondary forests, late secondary forests and 241 coffee plantations) showed a significant effect on total bee abundance $\left(F_{2,8}=7.92, p=0.01\right)$, bee 242 richness $\left(\mathrm{F}_{2,8}=6.38, \mathrm{p}=0.02\right)$, native bees $\left(\mathrm{F}_{2,8}=5.33, \mathrm{p}=0.03\right)$, stingless bees $\left(\mathrm{F}_{2,8}=8.41, \mathrm{p}=0.01\right)$, 243 social bees $\left(\mathrm{F}_{2,8}=9.01, \mathrm{p}=0.008\right)$, honey bees $\left(\mathrm{F}_{2,8}=6.2, \mathrm{p}=0.02\right)$, and Apidae and Megachilidae 244 families $\left(\mathrm{F}_{2,8}=10.01, \mathrm{p}=0.007, \mathrm{~F}_{2,8}=19.01, \mathrm{p}=0.0009\right.$, respectively), particularly between early 245 growth and coffee plantation (Fig. 4).

The diversity estimators Chao1, ACE, ICE (Fig. 5) calculated per farm and vegetation

247 type did not present any significant difference $(\mathrm{p}>0.05)$. The Chao2 estimator showed significant 248 differences among farms $\left(\mathrm{F}_{2,2}=7.903, \mathrm{p}=0.048\right)$. The Shannon-Wiener diversity index $(\mathrm{H})$ did not 249 present significant differences among farms. In farms 1 and 2, the richness estimators gave 250 higher values to plots with early secondary forest, while the highest estimate value on farm 3 was 251 for the coffee plantation. The species accumulation curves showed stabilized curves that started 252 to flatten down in some plots (Fig.6). Coffee plantations registered the lowest values in bee 253 diversity, and accordingly, the richness estimators predicted the lowest number of species (Fig. 5 254 and 7). In farms 1 and 2, the coffee plantations registered most of the bee records during the 
255 coffee flowering season (March 2014), otherwise, neither bee activity nor early growth

256 vegetation were recorded because coffee farmers clean adventive vegetation from coffee

257 plantations, particularly in farm 2. On farm 3, the coffee was rarely cleaned in this manner,

258 which contributed to the establishment of early secondary forest vegetation.

259 An important finding was the presence of a new species of bee genus Rhathymus

260 Lepeletier \& Serville, 1828, Rhathymus atitlanicus, described in Ayala, Hinojosa-Díaz \& Armas-

261 Quiñonez (2019). Those bees were only found in secondary forest of farm 1 and farm 3

262 (Appendix 2).

263 Finally, the cluster analysis of bee diversity per vegetation type (Fig. 8) presents a

264 significant pattern that groups the study plots into two significant aggregations. The strongest

265 aggregation with 97\% confidence is composed by the early secondary forests from farm 1 and

266 farm 3 and the coffee plots of farm 3 (the farm that allows secondary forest plants into the coffee

267 plantation). The other aggregation with $97 \%$ confidence, is composed by the coffee and late

268 secondary forests of all three farms. Within this group there are significant differences among the

269 plots of farm 1, where coffee is harvested following traditional practices, and on the other side of

270 the same group, is the late secondary forest linked with the coffee of farm 2. Cluster analysis

271 shows that the early secondary forest in farm 2 is $77 \%$ different to the rest of the plots.

272

273 Discussion

274 The effect of flowering seasonality on bees. The bees recorded over the whole year in

275 secondary forest and coffee fields could give an insight into the synchronization that exists

276 between bees and phenology of flowering plants, due to the periods of highest bee abundance

277 matching with flowering periods and the correlation between these parameters throughout the 
278 study. This correlation supports previous findings (Brosi, 2009, Banks et.al, 2014, De Marco and

279 Monteiro, 2004, Taki et al., 2013) about the great importance of secondary forests in the

280 provision of resources to bees. This seasonality can have some important consequences for bee

281 diversity but also for coffee production, since the highest abundances of native bees were

282 observed during secondary forest flowering (March 2014), close to the coffee flowering that

283 varies according to the first rains. Early flowering of coffee could coincide with secondary forest

284 flowering, which would cause native bees to interact with the high honey bee abundance

285 possibly giving rise to a saturated environment of pollinators for the coffee and secondary forest.

286 However, the asynchrony of pollinators and flowering periods in coffee fields must be treated

287 with care and taken into account in crop management as a priority for improved of coffee

288 production (Boreux et. al., 2013).

When investigating the relationship between honey bee and native bee abundance, we

290 found a positive correlation between them, as other studies in Mexican coffee plantations have

291 found (Badano and Vergara, 2011). This fact suggests that honey bees may not yet have

292 saturated this ecosystem, and that, according to Banks et al. (2013), the contribution of

293 pollinators from nearby forests to the coffee plantations is still high. This notion can be

294 supported by the fact that honey bees only maintain high populations during coffee flowering,

295 otherwise, their cultured populations are kept to a minimum in the area. However, the abundance

296 of the groups bees and the total of bees are showing differences between vegetation types

297 probably due to the nearby farm vegetation, especially surrounding secondary vegetation and

298 primary forest were the native bees usually nest (Vanddeler 2006). 
300 Secondary forests as coffee pollinator enhancers. The data of bee abundance, richness and

301 diversity supports the importance of secondary forests for bee pollinators (Arnan 2010,

302 Carvalheiro 2012, Banks et al. 2013, Brosi 2008; Boreux et al. 2013), not only to maintain bee

303 diversity, but also to improve coffee production in the Pacific Coast Foothills of Guatemala. The

304 significant results in the nested anovas remarks how the vegetation interact with bees, they are

305 most abundant in early secondary forests(Table 2). Meanwhile, the presence of stingless bees in

306 the secondary forests and also in the flowering coffee plants, suggests that these bees, which

307 depend exclusively on the forest for nesting, also depend on secondary forests for the acquisition

308 of essential resources (Winfree 2010, Vanddeler 2006).

309 Secondary forests showed that they can maintain and provide resources for the native

310 bees during periods when the coffee is not flowering. The farmers that use conventional

311 agriculture need to place greater emphasis on preserving secondary forests, rather than only

312 pristine forests (Blanque 2006). Pollination tests are required in order to compare the pollination

313 efficiency of native bees and honey bees in these plantations. In this way, it would be possible to

314 more definitively establish the importance of preserving native bees and the places where they

315 obtain resources, such as the secondary forest, for coffee production (Winfree 2010).

316

317 Effect of farm management. We found important differences in bee diversity between farms.

318 Farm 1 shows the highest diversity values, suggesting that, despite the lack of high technology,

319 traditional knowledge remains effective in preserving native bee diversity, especially for the

320 stingless bees. The conventional farm with high-intensive management (farm 2) keeps the coffee

321 plantations cleared of early secondary forest but maintains surrounding secondary vegetation on

322 the farm; therefore, the presence of Tephrosia spp. could function as a provision plant for native 
323 bee species. A positive interaction between farm 2 and bee family abundance can suggest the

324 importance of nearby forest, since the farm 2 manage their own forest reserve, providing the bees

325 with a complex landscape that may enhance bee resource acquisition, as suggested previously by 326 different authors (Carrié et. al. 2016, Winfree, et al., 2009).

327

328

329

330

331

332

333

334

336

337

338

339

340

341

342

343

\section{Conclusions}

Also, it is evident that the conventional farming with low-intensity management and a disturbed surrounding forest (farm 3) has the lowest bee diversity and, that it is the early secondary forest left in the coffee fields for a short time period that functions as resource provider for the surrounding bee diversity. This could explain why, in the cluster analysis (Fig. 8), the coffee of farm 3 was grouped together with the early secondary forest of farm 1 and 2. None of the studied farms use honey bee breeding to pollinate coffee at the time of this study. Some neighboring farms, however, do have managed bee hives and it is possible that the honey bees recorded during the study came from those neighboring farms. The farm with the closest neighboring honey bee hives was farm 3 , which showed the lowest bee abundance, richness and diversity values as well as the highest honey bee abundance. On the other hand, this farm (3) also shows a poor surrounding forest management providing few resources for native bees, contrary of farm 1 that promotes this mixed-landscape (Carrié et. al.2016). Another factor to consider that may affect bee diversity is the use of chemicals in the farms: the quantity of insecticides used for pest control inside (such as that used to control the Mediterranean fruit fly), but also those used outside farms in neighboring crops cultivated near coffee (Brittain et al. 2010; Schmitt 2009; Schuepp 2012).

Peer) reviewing PDF | (2020:02:45835:1:2:CHECK 30 Apr 2020) 
345 In coffee plantations the presence of secondary forest in the early growth stage, shows a

346 significant positive effect on bees, and taking into account the importance of bees for pollination

347 this is a natural way to increase the pollinators. Regarding farm management, this study can be

348 used to apply certain strategies that would benefit native bee diversity around the country.

349 Through incorporating some traditional farming techniques into conventional coffee field

350 management, such as letting the surrounding secondary forests grow at least in the early dry

351 season, it can be demonstrated that these provide floral resources for native bees that will also

352 visit the coffee during its flowering stage. Our results also support the value of traditional

353 farming, which in this study demonstrated a high diversity of native bees, capable of pollinating

354 small coffee plots and thus saving the cost of maintaining honey bee hives for pollinating small

355 crops. However our sampling effort was restricted to three farms in a particular region of

356 Guatemala, therefore in order to be able to generalize our findings we should increase our

357 sampling effort.

358

\section{Acknowledgements}

360 We gratefully acknowledge to the "Posgrado en Ciencias Biológicas, UNAM". This publication

361 of Gabriela Armas is part of the doctoral thesis in the "Programa de Doctorado en Ciencias

362 Biológicas, Universidad Nacional Autónoma de México (UNAM)”. We also acknowledge to the

363 farms personnel for their help with the field work and the farm owners and communitarians who

364 allowed the entrance and the data record on their properties. We sincerely acknowledge to the

365 "Laboratorio de Entomología Aplicada y Parasitología", "Programa de Experiencias Docentes

366 con la Comunidad" and "Centro de Estudios Conservacionistas", Universidad de San Carlos de 
367 Guatemala, for having provided materials and equipment during the collection, processing and 368 data analysis.

369

\section{References}

371 Abrol DP, Shankar U, Chatterjee D, Ramamurthy VV. 2012. Exploratory studies on diversity of

372 bees with special emphasis on non_Apis pollinators in some natural and agricultural plants of

373 Jammu division, India Current Science. 103: 780-783.

374

375 Ayala BR. 1990. Abejas silvestres (Hymenoptera: Apoidea) de Chamela, Jalisco, México. Folia 376 Entomológica Mexicana 77(1988): 395-493.

377

378

379

Ayala R. 1999. Revisión de las abejas sin aguijón de México (Hymenoptera: Apidae:

Meliponini). México: Folia Entomológica Mexicana 106: 1-123.

380

381

Ayala, R., Hinojosa-Díaz, I. A., Armas-Quiñónez, A. G. 2019. A new species of Rhathymus

382 Lepeletier \& Serville, 1828 (Hymenoptera: Apidae: Rhathymini) from Guatemala. Zootaxa 4700

383 (1): 132.138 DOI: 10.11646/zootaxa.4700.1.7.

384

385

Asociación Nacional del Café (ANACAFE). 2014. El Cafetal: La Revista del Caficultor.

386

Guatemala No. 40: 1-24.

387

388

Badano EI, Vergara CH, 2011. Potential negative effects of exotic honey bees on the diversity

389

of native pollinators and yield of highland coffee plantations. Agricultural and Forest

390

Entomology 13: 365-372 DOI: 10.1111/j.1461-9563.2011.00527.x.

391

392

Banks JE, Hannon L, Hanson P, Dietsch T, Castro S, Urena N, Chandler M. 2013. Effects of

393 proximity to forest habitat on hymenoptera diversity in a Costa Rican coffee agroecosystem.

394 Pacific Coast Entomological Society. Pan-Pacific Entomologist 89(1): 60-68 DOI:

395 10.3956/2012-28.1.

396

397

Banks JE, Hannon LM, Dietsch TV, Chandler M, 2014. Effects of seasonality and farm

398 proximity to forest on Hymenoptera in Tarrazú coffee farms, International Journal of

399 Biodiversity Science Ecosystem Services Management 10(2): 128-132 DOI:

400 10.1080/21513732.2014.905494.

401

402

Blanque KR, Ludwing JA, Cunningham SA, 2006. Proximity to rainforest enhances pollination

403 and fruit set in orchards. Journal of Applied Ecology 43: 1182-1187 DOI: 10.1111/j.1365-

404 2664.2006.01230.x. 
405

406

407

408

409

410

411

412

413

414

415

416

417

418

419

420

421

422

423

424

425

426

427

428

429

430

431

432

433

434

435

436

437

438

439

440

441

442

443
Boreux V, Kushalappa CG, Vaast P, Ghazoul J. 2013. Interactive effects among ecosystem services and management practices on crop production: Pollination in coffee agroforestry systems. PNAS. 110: 8387-8392. DOI: 10.1073/pnas.1210590110.

Brauman KA, Daily GC. 2008. Ecosystem Services. Human Ecology 1148-1154p.

Brittain C, Bommarco R, Vighi M, Barmaz S, Settele J, Potts SG. 2010. The impact of an insecticide on insect flower visitation and pollination in an agricultural landscape. Agricultural and Forest Entomology 12: 259-266 DOI: 10.1111/j.1461-9563.2010.00485.x.

Brosi, B.J., Daily, G.C., Shih, T.M., Oviedo, F., Durán, G., 2008. The effects of forest fragmentation on bee communities in tropical countryside. Journal of Applied Ecology 45: 773783 DOI: 10.1111/j.1365-2664.2007.01412.x.

Brosi BJ. 2009. The complex responses of social stingless bees (Apidae: Meliponini to tropical deforestation. Forest Ecology and Management 2009: 1830-1837 DOI:

10.1016/j.foreco.2009.02.025.

Cariveau DP, Winfree R. 2015. Causes of variation in wild bee responses to anthropogenic drivers. Current Opinion in Insect Science 10:104-109 DOI: 10.1016/j.cois.2015.05.004.

Carvalheiro LG, Seymour CL, Nicolson SW, Veldtman R. 2012. Creating patches of native flowers facilitates crop pollination in large agricultural fields: mango as a case study. Journal of Applied Ecology 49:1373-1383 DOI: 10.1111/j.1365-2664.2012.02217.x.

Colwell RK, 2013. Stadistical estimation of species richness and shared species from samples. Version 9. Persistent URL: purl.oclc.ort/estimates.

Consejo Nacional de Áreas Protegidas (CONAP). 2008. Guatemala y su Biodiversidad: Un enfoque histórico, cultural, biológico y económico. Documento Técnico 67 (06-2008): 1-51.

De Marco Jr, Monteiro P, Coelho F. 2004. Services performed by the ecosystem: forest remnants influence agricultural cultures' pollination and production. Biodiversity Conservation 13:12451255.

Donald PF. 2004. Biodiversity impacts of some agricultural commodity production systems. Issues in International Conservation. Conservation Biology 18(1): 17-37.

Peer] reviewing PDF | (2020:02:45835:1:2:CHECK 30 Apr 2020) 
444 Enríquez E, Yurrita C, Ayala R, Marroquin A, Griswold T. 2012. Diversidad de abejas silvestres 445 (Hymenoptera: Apoidea) de Guatemala. In: Enio B Cano and J. C. Schuster (Editors).

446 Biodiversidad De Guatemala 2: 281-299.

447

448 Fischer EF, Victor B. 2014. High-end coffee and smallholding growers in Guatemala. Latin 449 American Studies Association. Latin American Research Review 49: 155-177.

450

451

Garibaldi LA, Steffan-Dewenter I, Kremen C, Morales JM, Bommarco R, Cunningham SA, 452 Carvalheiro L, Chacoff N, Dudenhöffer J, Greenleaf S, Holzschuh A, Isaacs R, Krewenka, K, 453 Mandelik Y, Mayfield M, Morandin L, Potts S, Ricketts T, Szentgyörgyi H, Viana B, Westphal 454 C, Winfree R, Klein A. 2011. Stability of pollination services decreases with isolation from 455 natural areas despite honey bee visits. Ecology. Letters 14: 1062-1072 DOI: 10.1111/j.1461456 0248.2011.01669.x.

457

458

459

460

461

462

463

464

465

466

467

468

469

470

471

472

473

474

475

476

477

478

479

480

481

482

483

Jha S, Dick CW. 2010. Native mediate long-distance pollen dispersal in a shade coffee landscape mosaic. PNAS Early Edition. 5pp.

Klein AM, Cunningham SA, Bos M, Steffan-Dewenter I. 2008. Advances in pollination ecology from tropical plantation crops. Ecological Society of America. Ecology 89(4): 935-943.

Klein AM, Vaissie`re B, Cane JH, Steffan-Dewenter I, Cunningham SA, Kremen C. 2007. Importance of crop pollinators in changing landscapes for world crops. Proceedings of the Royal Society B: Biological Science 274:303-313.

Klein AM, Dewenter I, Tsccharntke T. 2003. Pollination of Coffea canephora in relation to local and regional agroforestry management. Journal of Applied Ecology 40: 837- 845.

Kremen C, Williams NM, Thorp RW. 2002. Crop pollination from native bees at risk from agricultural intensification. PNAS. Vol. 99, no. 26. 16812-16816 DOI: 10.1073/pnas.262413599.

Kremen C, Williams NM, Bugg RL, Fay JP, Thorp RW. 2004 The area requirements of an ecosystem service: crop pollination by native bee communities in California. Ecology Letters 7:1109-1119 DOI: 10.1111/j.1461-0248.2004.00662.x.

Kremen C, Williams NM, Aizen MA, Gemmil-Herren B, LeBuhn G, Minckley R, Packer L, Potts SG, Roulston T, Steffan-Dewenter IS, Vasquez D, Winfree R, Adams L, Crone EE, Greenleaf SS, Keitt TH, Klein AM, Regetz J, Ricketts TH. 2007. Pollination and other ecosystem services produced by mobile organisms: a conceptual framework for the effects of land-use change. Ecology Letters 10: 299-314 DOI: 10.1111/j.1461-0248.2007.01018.x. 
484 Labougle JM. 1990. Bombus of Mexico and Central America (Hymenoptera, Apidae).

485 University of Kansas Science Bulletin 54: 35-73.

486

487

488

489

490

491

492

493

494

495

496

497

498

499

500

501

502

503

504

505

506

507

508

509

510

511

512

513

514

515

516

517

518

519

520

521

522

523

Mandelik Y, Roll U. 2009. Diversity patterns of wild bees in almond orchards and their surrounding landscape. Israel Journal Plant Science 57: 185-191 DOI: 10.1560/IJPS.57.3.185.

McGavin GC. 1997. Expedition Field Techniques: Insects and other terrestrial arthropods.

Geography Outdoors: the center supporting field research, exploration and outdoor learning. London. 1-96.

McGinley RJ. 1986. Studies of Halictinae (Apoidea: Halictidae), I: Revision of new world Lasioglossum Curtis. Smithsonian Contributions to Zoology No. 429: 1-294.

McMullen RD. 1965. The insect collector's guide. Entomological Society of Alberta. 1-24.

Michener CD. 2007. The Bees of the world. Baltimore: Johns Hopkins University Press.

Michener, CD, McGinley, RJ and Danforth, BN. 1994. The Bee Genera of North and Central America (Hymenoptera: Apoidea). Smithsonian Institution.

Montero-Castaño A., Vilà, M. 2012. Impact of landscape alteration and invasions on pollinators: a meta-analysis. British Ecological Society. Journal of Ecology 100: 884-893 DOI:

10.111/j.1365-2745.2012.01968.x.

National Congress of Guatemala. 1989. Congress Decrees. No. 4-89. República de Guatemala. 1-44.

Ngo, HT, Mojica AC, Packer, L. 2011. Coffee plant-pollinator interactions: a review. Canadian Journal of Zoology 89(8): 647-660.

O’Brien LB, Hurd PD Jr. 1965. Carpenter bees of the subgenus Notoxylocopa. Annals of the Entomological Society of America 58: 175- 196.

Oksanen J, Blanchet FG, Friendly M, Kindt R, Legendre P, McGlinn D, Minchin PR, O'Hara RB, Simpson GL, Solymos P, Stevens MHH, Szoecs E, Wagner H. 2019. vegan: Community Ecology Package. $R$ package version 2.5-6. https:/CRAN.Rproject.org/package=vegan

Ollerton J, Winfree R, Tarrant S, 2011. How many flowering plants are pollinated by animals? Nordic Society Oikos. Oikos 120: 321-326 DOI: 10.1111/j.1600-0706.2010.18644.x. 
524

525

526

527

528

529

530

531

532

533

534

535

536

537

538

539

540

541

542

543

544

545

546

547

548

549

550

551

552

553

554

555

556

557

558

559

560

561

562
Peters VE, Carroll CR, Cooper RJ, Greenberg R, Solis M. 2013. The contribution of plant species with a steady-state flowering phenology to native bee conservation and bee pollination services. Insect Conservation Divers 6: 45-56 DOI: 10.1111/j.1752-4598.2012.00189.x.

Philpott SM, Arendt WJ, Armbrecht I, Bichier P, Diestch TV, Gordon C, Greenbeerg R, Perfecto I, Reynoso-Santos R, Soto-Pinto L, Tejeda-Cruz C, Williams-Linera G, Valenzuela J, Zolotoff JM. 2008. Biodiversity loss in Latin Americano coffee landscapes: Review of the evidence on Ants, Birds and Trees. Conservation Biology 22(5): 1093-1105.

Pinheiro J, Bates D, DebRoy S, Sarkar D, R. Core Team. 2020. nlme: Linear and Nonlinear Mixed Effects Models. R package version 3.1-145, https://CRAN.R-project.org/package=nlme.

Rao S, Stephen WP. 2010. Abundance and Diversity of Native Bumble Bees Associated with Agricultural Crops: The Willmette Valley Experience. Hindawi Publishing Corporation. Psyche 354072:1-9 DOI:10.1155/2010/354072.

Ricketts TH, 2004. Tropical forest fragments enhance pollinator activity in nearby coffee crops. Conservation Biology 18(5): 1262-1271.

Ricketts TH, Tegets J, Steffan-Dewenter I, Cunningham SA, Bogdanski A, Gemmill-Herren B, Greenleaf SS, Klein AM, Mayfield MM, Morandi LA, Ochieng A, Viana BF. 2008. Landscape effects on crop pollination services: Are there general patterns? Ecology Letters 11: 499-515. DOI: $10.1111 / \mathrm{j} .1461-0248.2008 .01157 . x$.

R Core Team. 2014. R: A Language and Environment for Statistical Computing. Vienna, Austria, http://www.R-project.org

Roberts RB. 1972. Revision of the bee genus Agapostemon. University of Kansas Science Bulletin 49: 437-590.

Roubik DW, Hanson PE. 2004. Orchid bees of tropical America biology and field guide, $370 \mathrm{pp}$. Santo Domingo de Heredia, Costa Rica: Instituto Nacional de Biodiversidad (INBio). [in Spanish and English.]

Shavit O, Dafni A, Ne'eman G. 2009 Competition between honeybees (Apis mellifera) and native solitary bees in the Mediterranean region of Israel - Implications for conservation, Israel Journal of Plant Science 57(3): 171-183 DOI:dx.DOI.org/10.1560/IJPS.57.3.171.

Peer] reviewing PDF | (2020:02:45835:1:2:CHECK 30 Apr 2020) 
563 Scheper J, Holzschuh A, Kuussaari M, Potts SG, Rundlöf M, Smith HG, Kleijn D. 2013.

564 Environmental factors driving the effectiveness of European agri-environmental measures in

565 mitigating pollinator loss -a meta-analysis. Ecology Letters 16: 912-920 DOI:

$56610.1111 /$ ele.12128.

567

568 Schmitt CB, Senbeta F, Denich M, Preisinger H, Juergen Boechmer H. 2009. Wild coffee

569 management and plant diversity in the montane rainforest of outhwester .Blackwell Publishing

570 Ltd. African Journal of Ecology 48: 78-86.

571

572 Schüepp C, Rittiner S, Entling MH. 2012. High Bee and Wasp Diversity in a Heterogeneous

573 Tropical Farming System Compared to Protected Forest. PLoS ONE 7(12), e52109

574 DOI:10.1371/journal.pone.0052109.

575

576 Smith-Pardo AH. 2005. The bees of the genus Neocorynura of Mexico. Folia Entomológica

577 Mexicana 44: 165-193.

578

579 Snelling RR. 1974. Notes on the distribution and taxonomy of some North American Centris.

580 Contributions in Science, Natural History Museum of Los Angeles County no. 259: 1-41.

581

582 Steffan-Dewenter I, Westphal C. 2008. The interplay of pollinator diversity, pollination services

583 and landscape change. British Ecological Society. Journal of Applied Ecology 45: 737-741 DOI:

584 10.1111/j.1365-2664.2008.01483.x.

585

586 Suzuki R, Terada Y, Shimodaira H. 2019. pvclust: Hierarchical Clustering with P-Values via

587 Multiscale Bootstrap Resampling. $R$ package version 2.2-0. https://CRAN.R-

588 project.org/package $=$ pvclust

589

590 Taki H, Makihara H, Matsumura T, Hasegawa M, Matsuura T, Tanaka H, Makino S, Okabe K.

591 2013. Evaluation of secondary forests as alternative to primary forests for flower-visiting insects.

592 Journal of Insect Conservation 17, 549-556. DOI: 10.1007/s10841-012-9539-3.

593

594 vanEngelsdorp D, Meixner MD, 2010. A historical review of managed honey bee populations in 595 Europe and the United States and the factors that may affect them. Journal of Invertebrate

596 Pathology 103(2010): 580-595.

597

598

Villar Anleu, L., 1998. La flora silvestre de Guatemala. USAC. Guatemala, 1-99.

599

600 Villar Anleu, L., 2003. Guatemala, un paraíso de la naturaleza. España, 1-143.

601 
602 Winfree R, Williams NM, Gaines H, Ascher JS, Kremen C. 2008. Wild bee pollinators provide 603 the majority of crop visitation across land-use gradients in New Jersey. Journal of Applied 604 Ecology 45: 793-802.

605

606 Winfree R, Wiliams NM, Dushoff J, Kremen C, 2007. Native bees provide insurance against 607 ongoing honey. Ecology Letters 10: 1105-1113 DOI: 10.1111/j.1461-0248.2007.01110.x 608

609 Winfree R, Aguilar R, Vázquez DP, LeBuhn, G, Aizen MA, 2009. A meta-analysis of bees' 610 responses to anthropogenic disturbance. Ecology 90(8): 2068-2076.

611

612 Winfree R. 2010. The conservation and restoration of wild bees. New York Academy of

613 Sciences. Annals of the New York Academy of Sciences 1195: 169-197 DOI: 10.1111/j.1749-

614 6632.2010.05449.x.

615

616 Winfree R, Bartomeus I, Cariveau DP. 2011. Native pollinators in anthropogenic habitats.

617 Annual Review of Ecology, Evolution and Systematics 42, 1-22. DOI: 10.1146/annurev-ecolsys618 102710-145042. 
Figure 1

Bee richness and plant richness

Figure 1. Pearson correlations between: (a) Bee richness and plant richness $(r=0.79$, $\left.p=2.8 e^{-09}\right)$. (b) Honeybee and stingless bee abundance $\left(r=0.62, p=2.95 e^{-05}\right)$. (c) Honeybee and native bee abundance $\left(r=0.61, p=4.84 e^{-05}\right)$. 
a

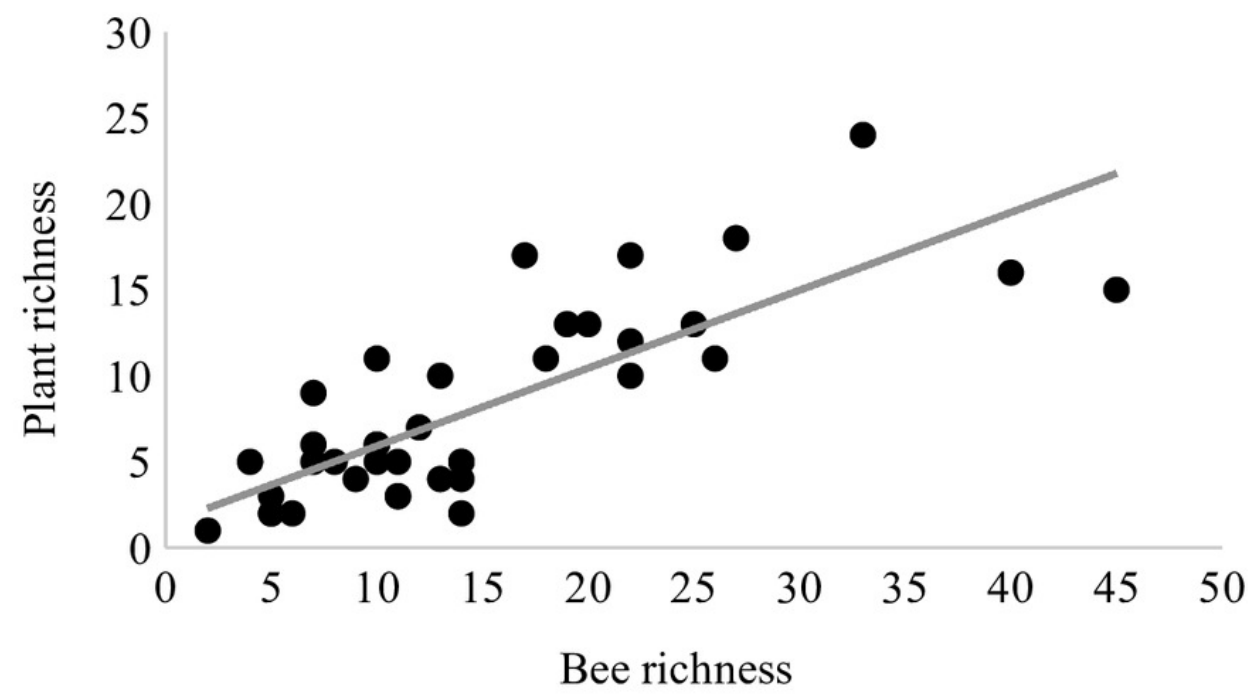

b

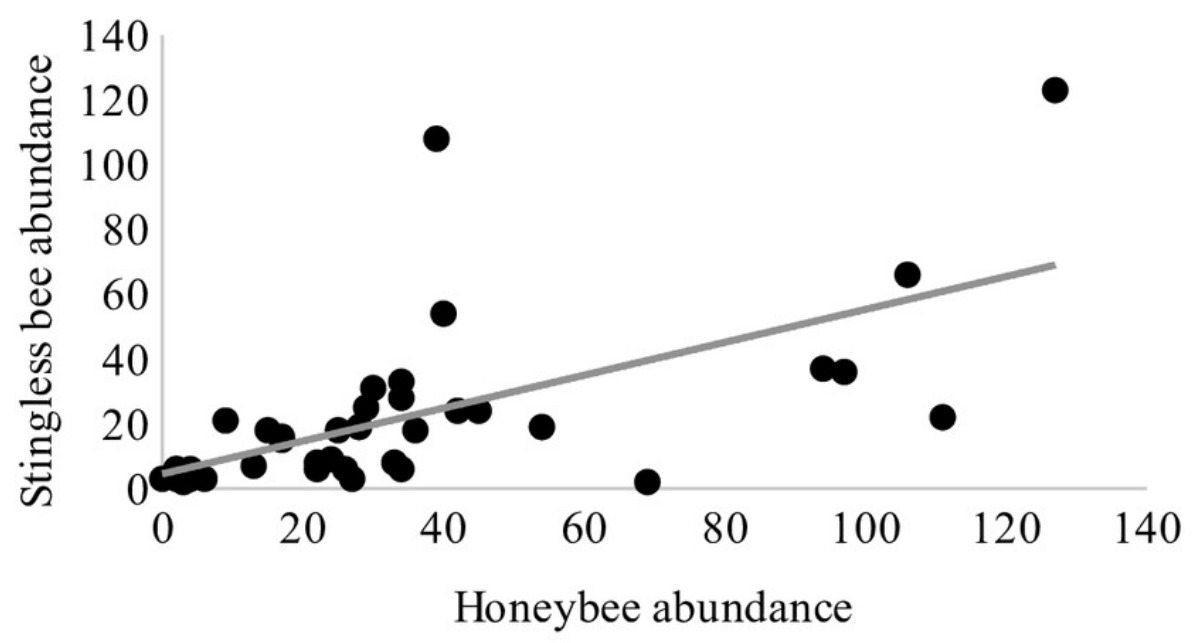

$\mathrm{C}$

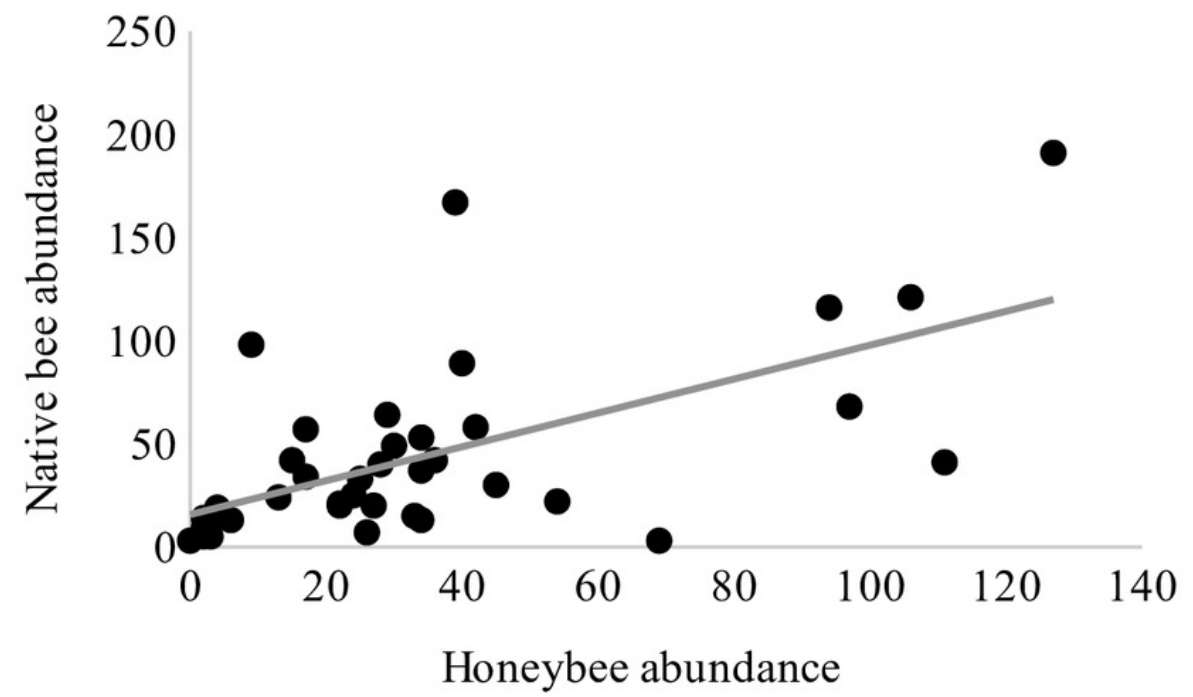


Figure 2

Bee and flower through time

Figure 2. Variation of bee and flowering plant richness in months in which the samplings were conducted highlighting the two climatic seasons for the region

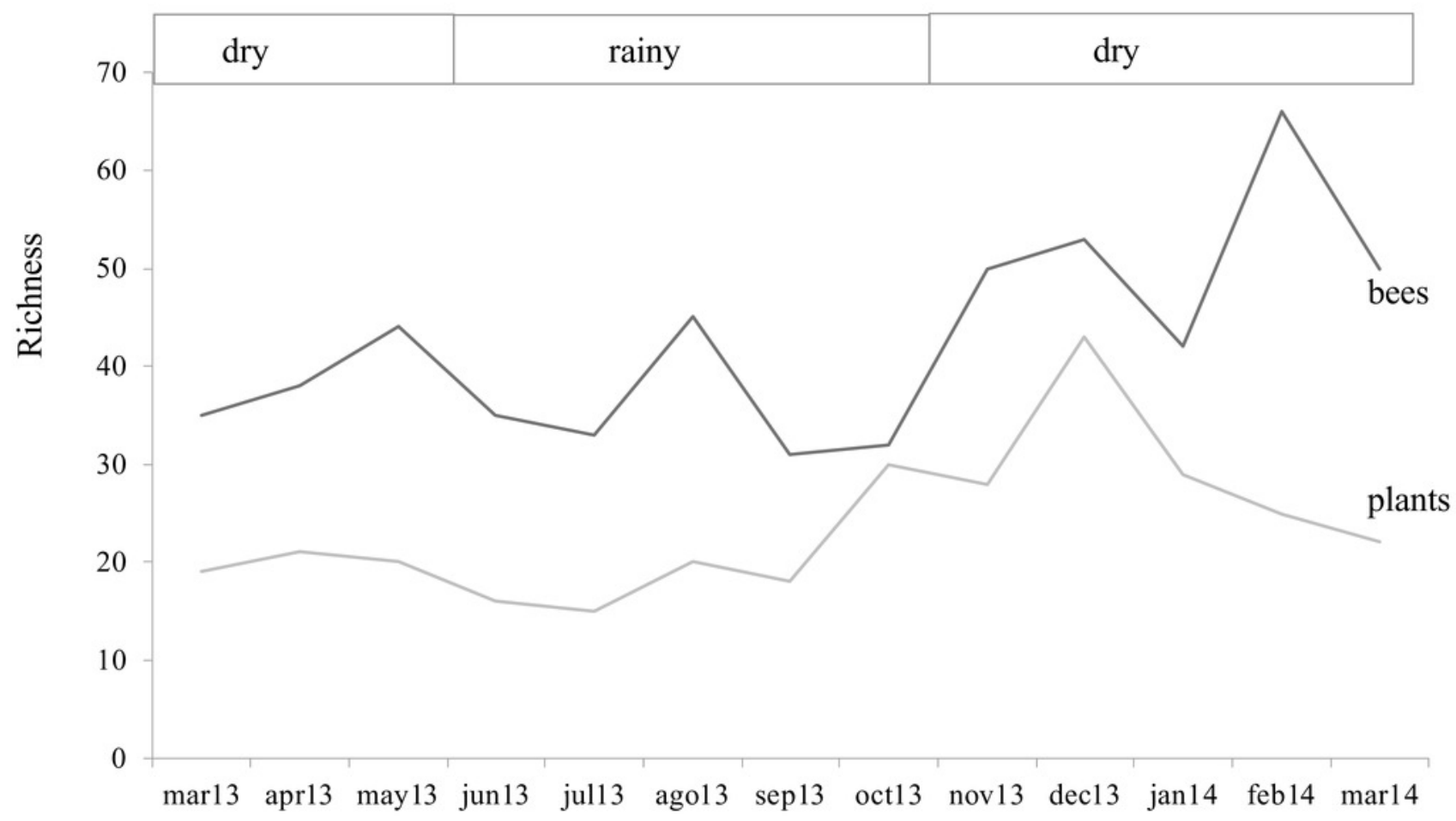


Figure 3

Total bee abundance per farm and vegetation type

Figure 3. Total bee abundance per farm and type plots. Cumulative abundance records per farm and plot are shown in the upper part of the figure. The lower table shows the total abundance of records per bee family.

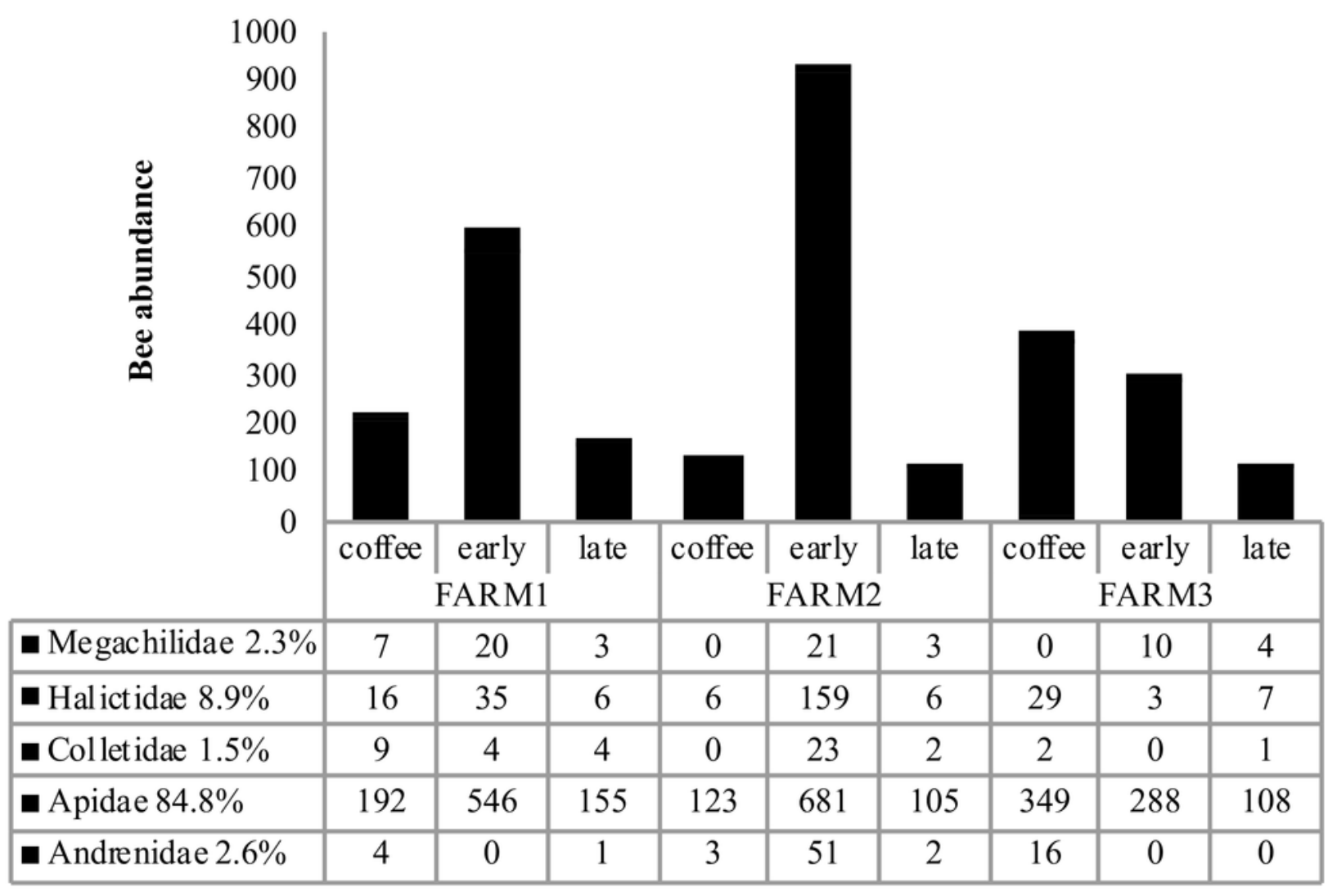


Figure 4

Bee diversity per farm

Figure 4. Bee abundance per farm and vegetation type plots. Honeybee abundance is shown in black, native bee abundance in light grey and stingless bee abundance in dark grey.

800

700

600

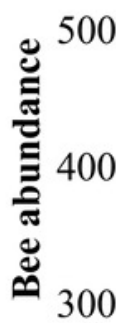

200

100

0

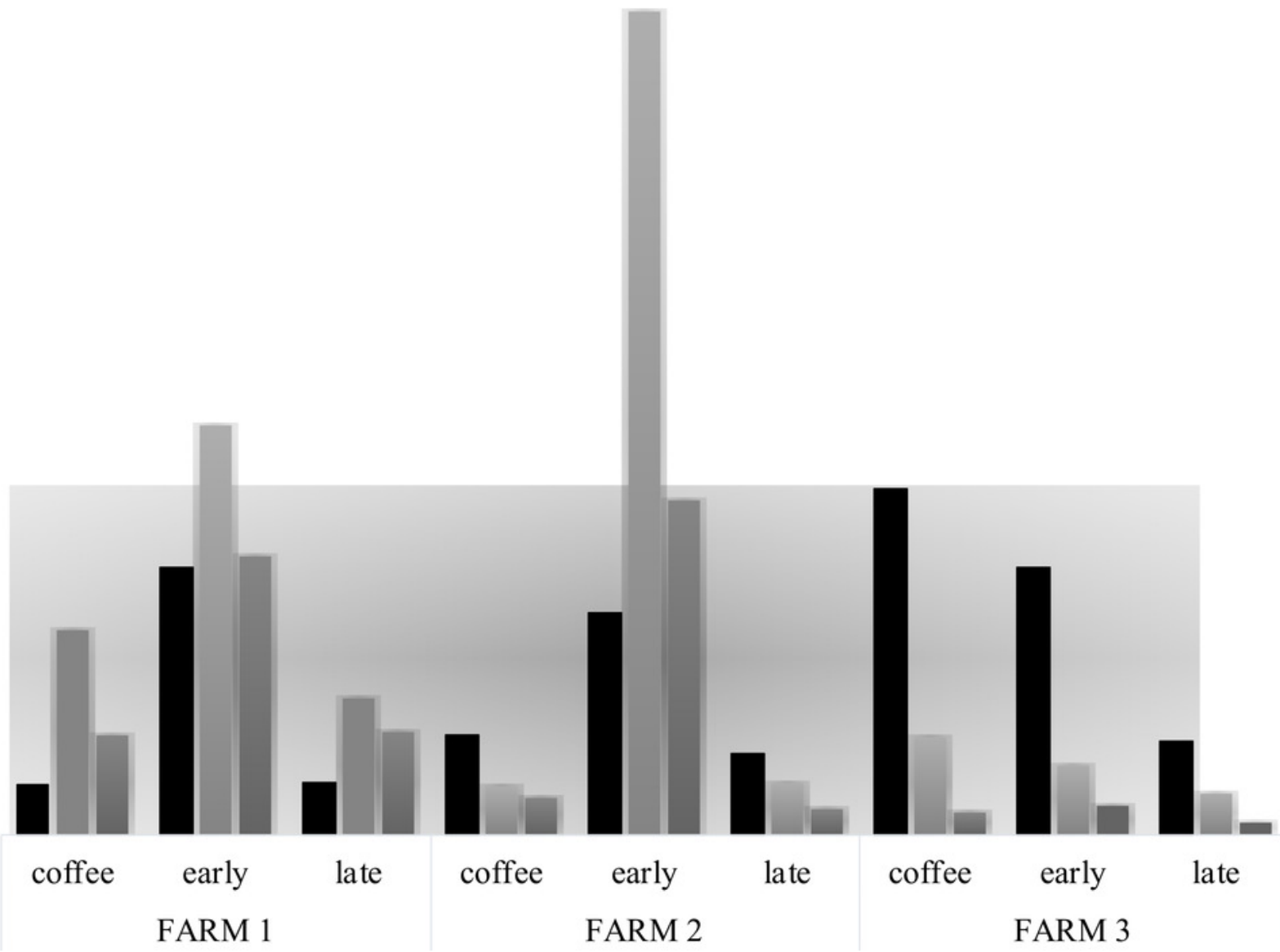


Figure 5

Bee diversity per farm and vegetation type

Figure 5. Bee species diversity per farm and vegetation type plots. (S) Bee richness. (ACE) Abundance-base coverage richness estimator $-\mathrm{S}_{\mathrm{ACE} .}$ (ICE) Incidence coverage estimator - $\mathrm{S}_{\text {ICE }}$ (Chao1) Richness estimator $-\mathrm{S}_{\mathrm{Chao1}^{-}}$. (Chao2) Incidence estimator $-\mathrm{S}_{\mathrm{Chao2}^{-}}$. Coffee plots are shown in pannels a,d,g; Early secondary forests in pannels b,e,h and Late secondary forests in pannles $\mathrm{c}, \mathrm{f}, \mathrm{i}$

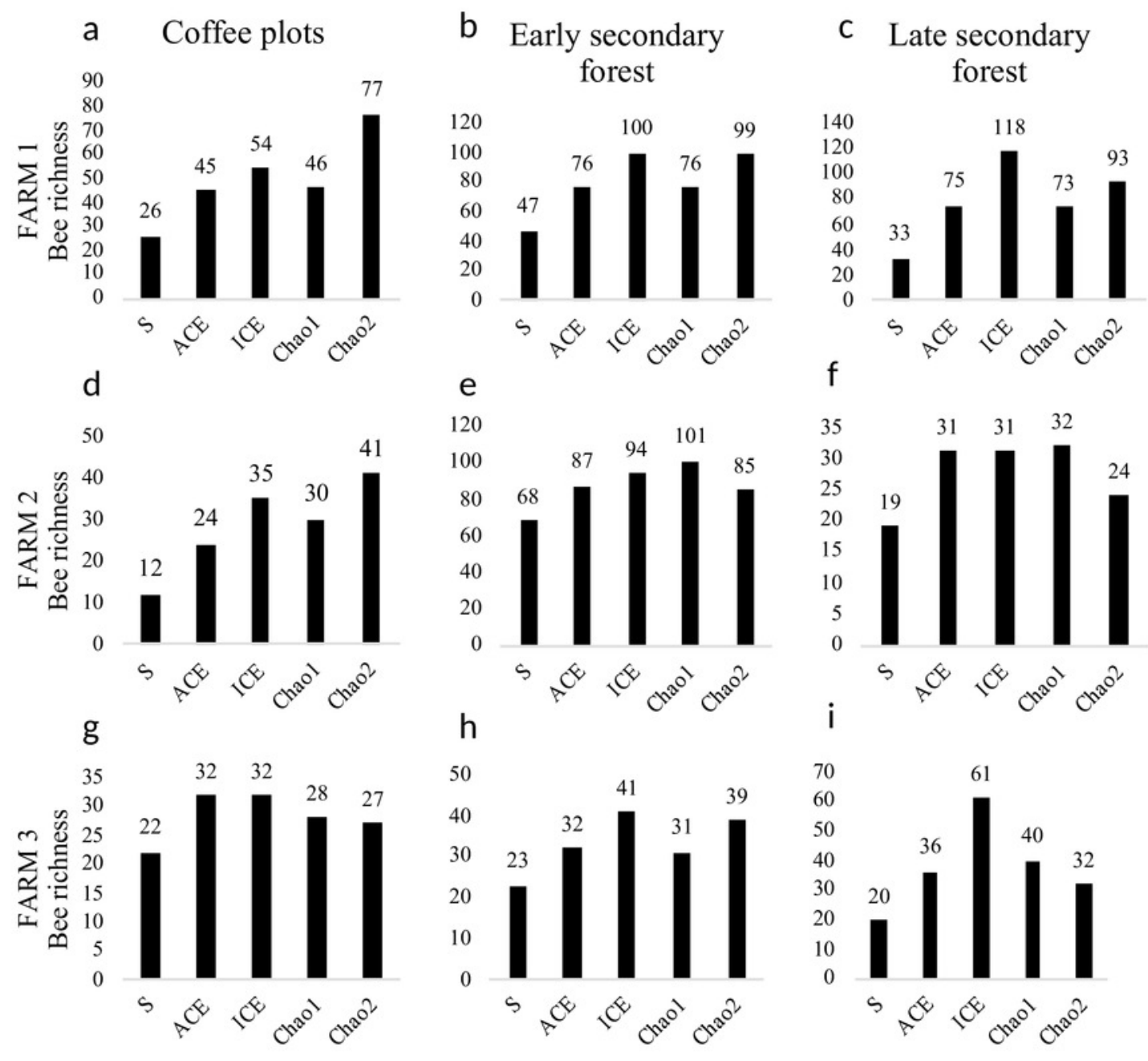


Figure 6

Species accumulation curves

Figure 6. Species accumulation curves of bee richness obtained in the study per farm and vegetation type plots. Coffee plots are shown in pannels a,d,g, Early secondary forests in pannels b,e,h and Late secondary forests in pannles $c, f, i$

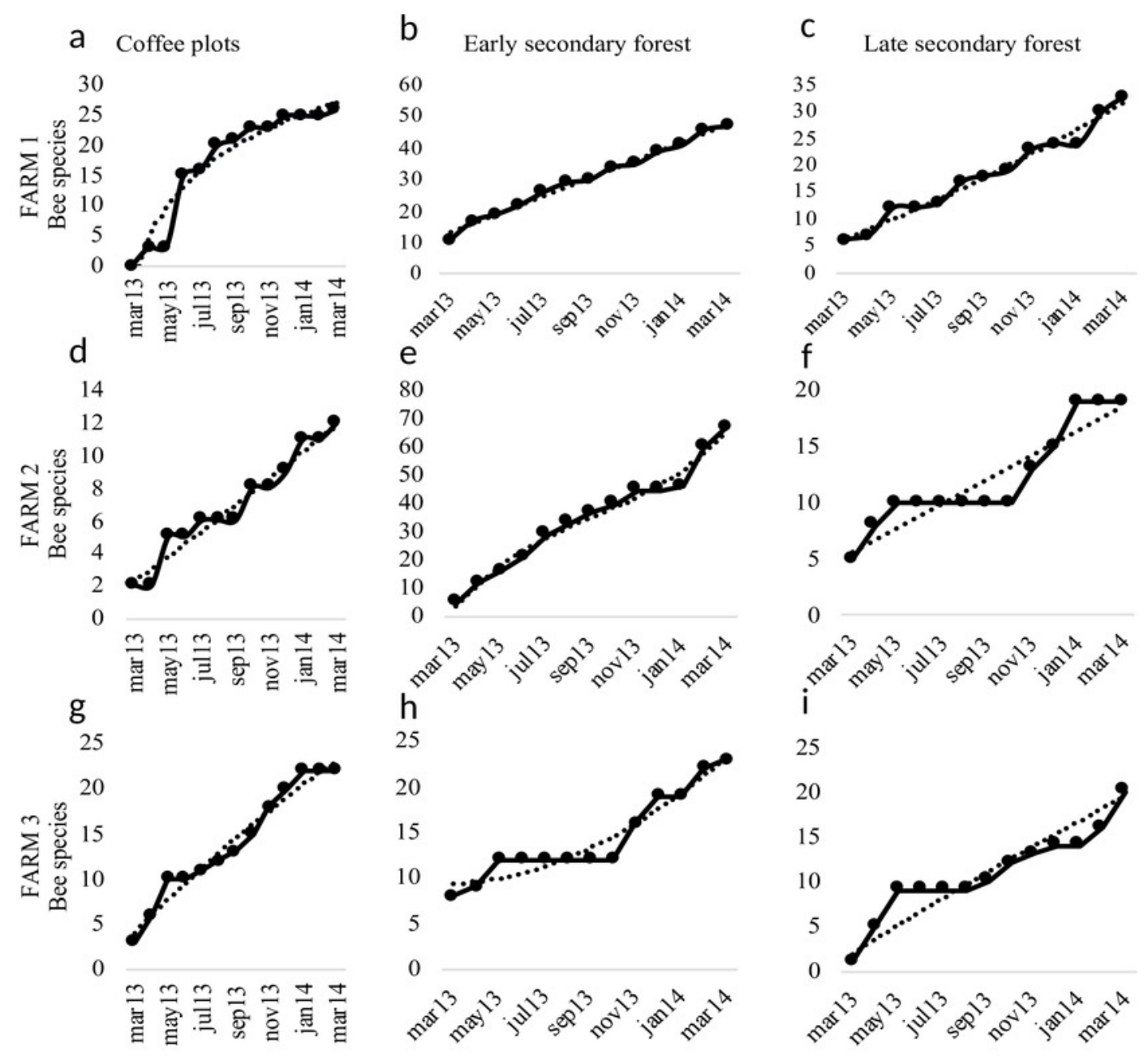




\section{Figure 7}

Bee richness per far, and plot type

Figure 7. a) Total bee richness and b) abundance registered per vegetation type plots.

Black bars show farm 1 data, light grey bars show farm 2 data and dark grey bars show farm 3 data. The total richness and abundance values are shown in the numbers above the bars.
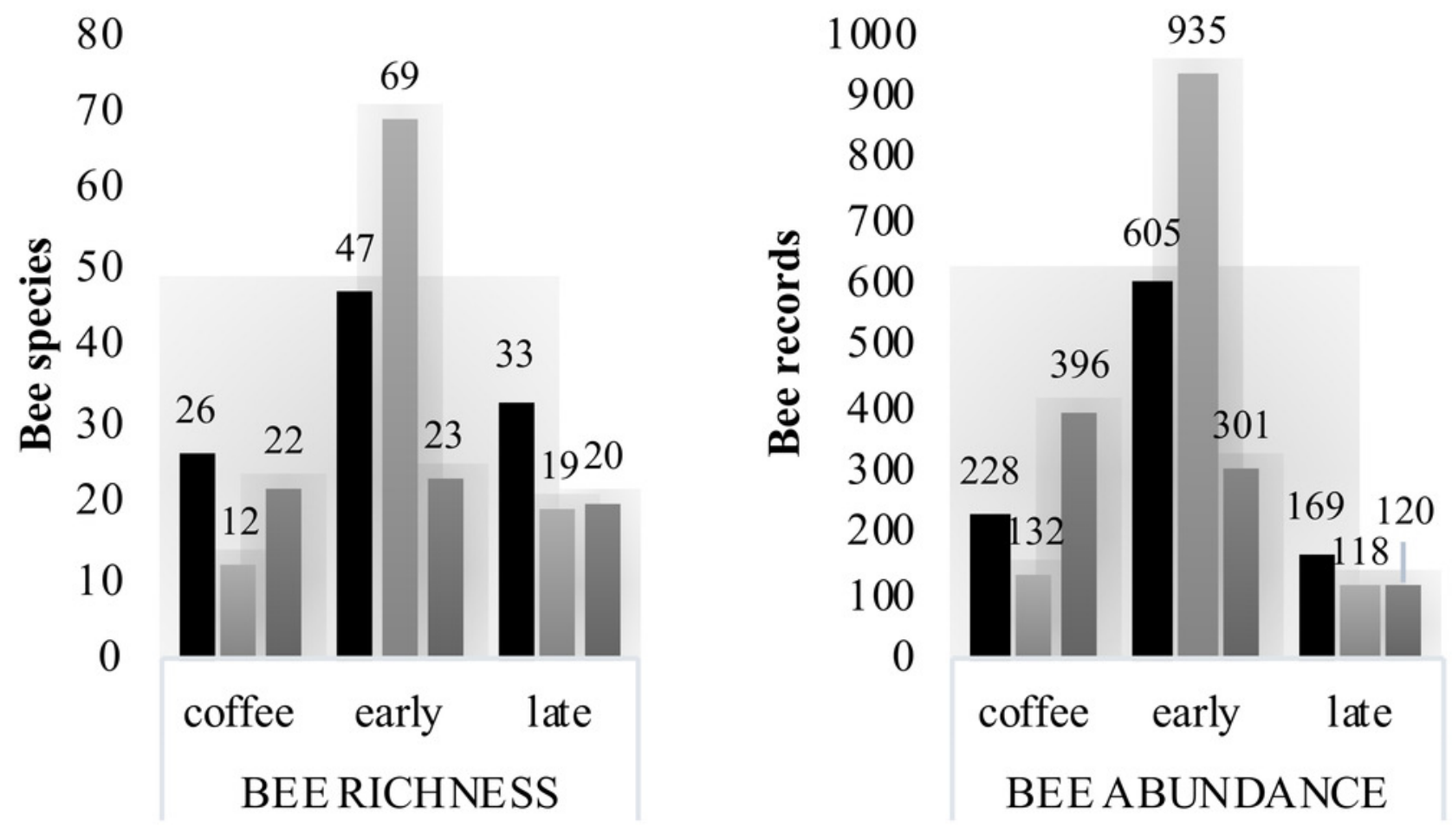
Figure 8

Dendrogram of bee species composition per farm and plot type

Figure 8. Cluster dendrogram of bee species abundances recorded between plots of the three farms (cluster analysis calculated in R using Vegan and Pvclust packages and Euclidean distance). Thep-value is shown at the top of each edge, presented as a percentage value of confidence, in which a value of 95 or higher represents a significant supported data aggregation. The two significantly different groups are indicated by red rectangles.

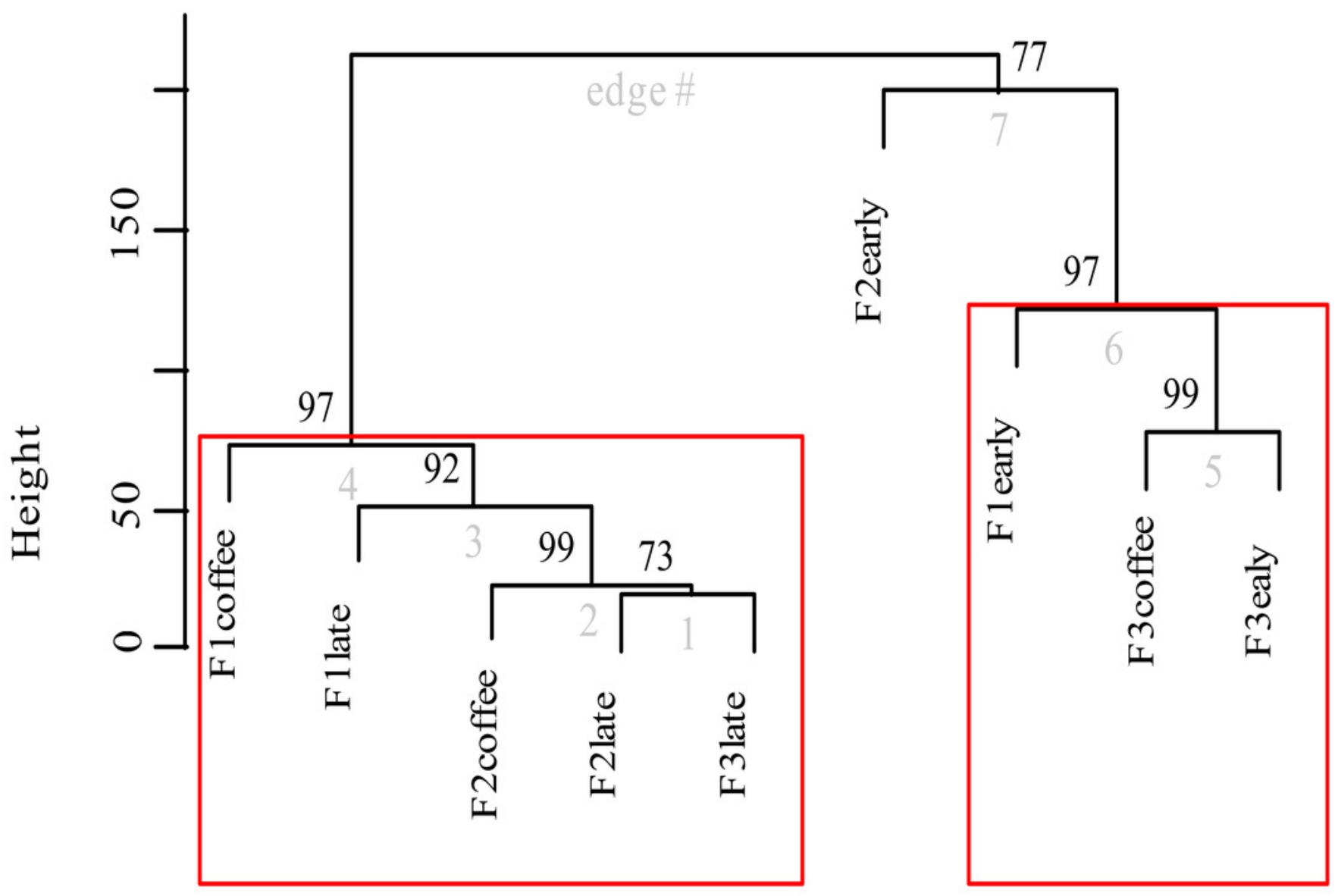




\section{Table 1 (on next page)}

Description of plots for the three studied sites.

Table 1. Description of plots for the three studied sites. 
1 Table 1. Description of plots for the three studied sites.

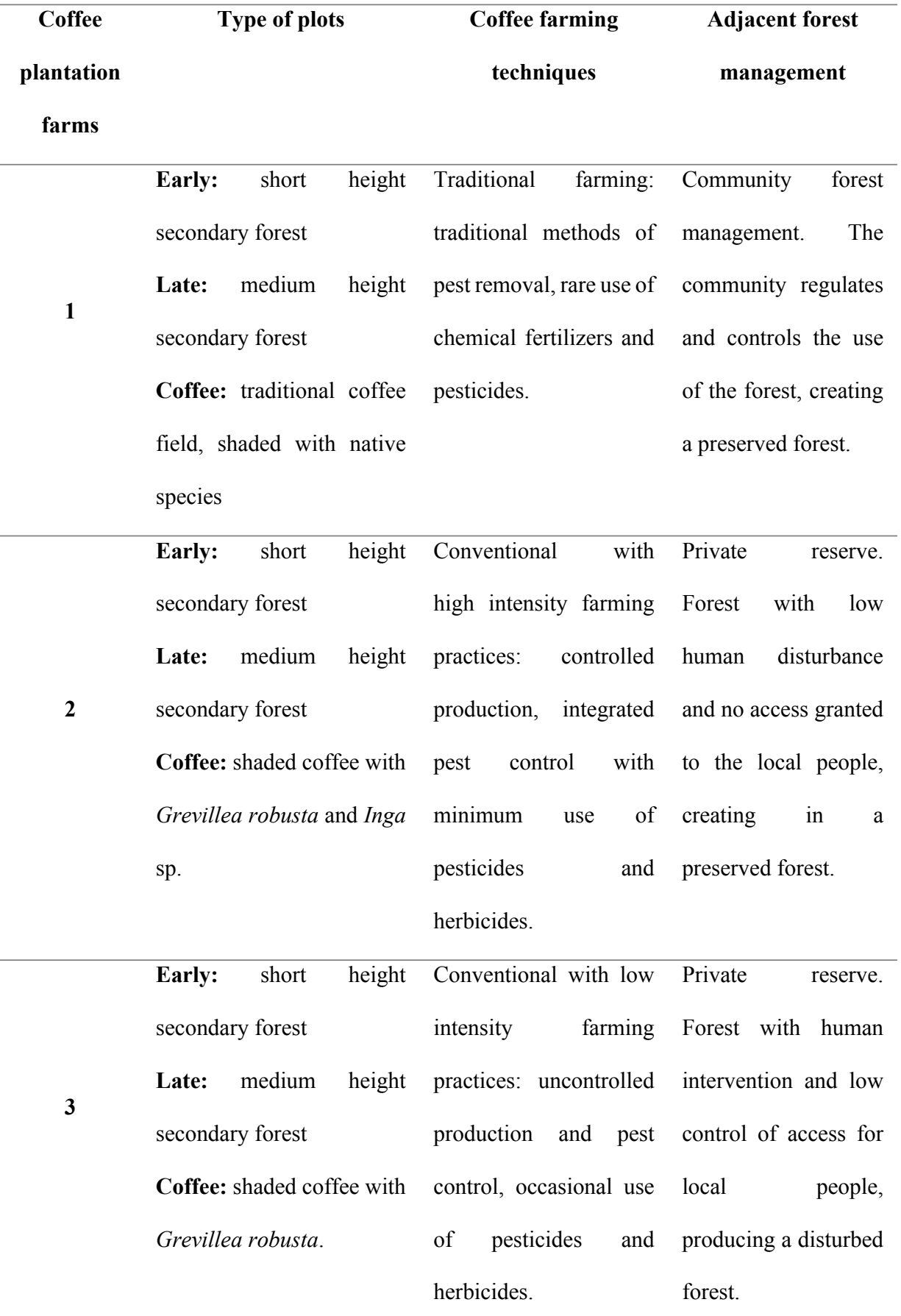




\section{Table 2 (on next page)}

Nested anova results

Table 2. Nested Anova results with significant $p$ values shown in bold numbers. 
1 Table 2. Nested Anova results with significant $p$ values shown in bold numbers.

\begin{tabular}{|c|c|c|c|c|c|c|c|c|c|c|c|c|c|c|c|c|c|c|c|c|c|c|c|c|c|}
\hline \multirow{2}{*}{$\begin{array}{l}\text { Variable } \\
\quad \mathrm{s}\end{array}$} & \multirow{2}{*}{$\begin{array}{l}\text { d } \\
\text { f }\end{array}$} & \multicolumn{2}{|c|}{$\begin{array}{c}\text { Honey } \\
\text { bees }\end{array}$} & \multicolumn{2}{|c|}{$\begin{array}{c}\text { Native } \\
\text { bees }\end{array}$} & \multicolumn{2}{|c|}{$\begin{array}{c}\text { Stingless } \\
\text { bees }\end{array}$} & \multicolumn{2}{|c|}{$\begin{array}{c}\text { Social } \\
\text { bees }\end{array}$} & \multicolumn{2}{|c|}{$\begin{array}{c}\text { Total bee } \\
\text { abundan } \\
\text { ce }\end{array}$} & \multicolumn{2}{|c|}{$\begin{array}{c}\text { Total } \\
\text { bee } \\
\text { richness }\end{array}$} & \multicolumn{2}{|c|}{$\begin{array}{c}\text { Plant } \\
\text { richness }\end{array}$} & \multicolumn{2}{|c|}{$\begin{array}{c}\text { Andrenid } \\
\text { ae }\end{array}$} & \multicolumn{2}{|c|}{ Apidae } & \multicolumn{2}{|c|}{$\begin{array}{c}\text { Colletida } \\
\text { e }\end{array}$} & \multicolumn{2}{|c|}{$\begin{array}{c}\text { Halictid } \\
\text { ae }\end{array}$} & \multicolumn{2}{|c|}{$\begin{array}{c}\text { Megachilid } \\
\text { ae }\end{array}$} \\
\hline & & $\mathrm{F}$ & $\mathrm{p}$ & $\mathrm{F}$ & $\mathrm{p}$ & $\mathrm{F}$ & $\mathrm{p}$ & $\mathrm{F}$ & $p$ & $\mathrm{~F}$ & $\mathrm{p}$ & $\mathrm{F}$ & $\mathrm{p}$ & $\mathrm{F}$ & $\mathrm{p}$ & $\mathrm{F}$ & $\mathrm{p}$ & $\mathrm{F}$ & $\mathrm{p}$ & $\mathrm{F}$ & $p$ & $\mathrm{~F}$ & $\mathrm{p}$ & $\mathrm{F}$ & $\mathrm{p}$ \\
\hline Season & $\begin{array}{l}1, \\
1\end{array}$ & $\begin{array}{c}19 . \\
1\end{array}$ & $\begin{array}{c}0.1 \\
4\end{array}$ & $\begin{array}{c}195 . \\
4\end{array}$ & $\begin{array}{l}0.0 \\
5\end{array}$ & 72. & $\begin{array}{c}0.0 \\
7\end{array}$ & $\begin{array}{c}118 . \\
5\end{array}$ & 0.05 & 40.6 & $\begin{array}{c}0.0 \\
9\end{array}$ & 66. & 0.0 & $\begin{array}{c}2.5 \\
3\end{array}$ & 0.3 & 1.69 & 0.41 & $\begin{array}{c}3999 \\
8\end{array}$ & 0.01 & $\begin{array}{c}27.8 \\
2\end{array}$ & $\begin{array}{c}0.1 \\
1\end{array}$ & 1.3 & $\begin{array}{c}0.4 \\
5\end{array}$ & 0.71 & 0.75 \\
\hline $\begin{array}{l}\text { Vegetati } \\
\text { on type }\end{array}$ & $\begin{array}{l}2, \\
8\end{array}$ & 6.2 & $\begin{array}{c}0.0 \\
2\end{array}$ & 5.33 & $\begin{array}{r}0.0 \\
3\end{array}$ & 8.4 & $\begin{array}{c}0.0 \\
1\end{array}$ & 9.01 & $\begin{array}{c}0.00 \\
8\end{array}$ & 7.92 & $\begin{array}{c}0.0 \\
1\end{array}$ & 6.3 & 0.0 & $\begin{array}{c}6.9 \\
5\end{array}$ & 0.0 & 0.82 & 0.47 & $\begin{array}{c}10.0 \\
1\end{array}$ & $\begin{array}{c}0.00 \\
7\end{array}$ & 0.84 & $\begin{array}{c}0.4 \\
6\end{array}$ & 2.4 & $\begin{array}{c}0.1 \\
5\end{array}$ & $\begin{array}{c}19.0 \\
1\end{array}$ & $\begin{array}{c}0.000 \\
9\end{array}$ \\
\hline $\begin{array}{l}\text { Season: } \\
\text { vegetatio } \\
\text { n type }\end{array}$ & $\begin{array}{l}4, \\
8\end{array}$ & 2.8 & $\begin{array}{c}0.1 \\
2\end{array}$ & 0.27 & $\begin{array}{r}0.7 \\
7\end{array}$ & $\begin{array}{c}0.3 \\
6\end{array}$ & $\begin{array}{c}0.7 \\
1\end{array}$ & 2.39 & 0.15 & 1.58 & $\begin{array}{c}0.2 \\
6\end{array}$ & 0.7 & $\begin{array}{c}0.5 \\
1\end{array}$ & $\begin{array}{c}0.3 \\
1\end{array}$ & $\begin{array}{c}0.7 \\
4\end{array}$ & 0.06 & 0.93 & 0.59 & 0.57 & 0.29 & $\begin{array}{c}0.7 \\
5\end{array}$ & $\begin{array}{c}0.0 \\
1\end{array}$ & $\begin{array}{c}0.9 \\
8\end{array}$ & 3.59 & 0.08 \\
\hline
\end{tabular}

